\title{
CHEMICAL CHARACTERIZATION OF Lippia alba ESSENTIAL OIL: AN ALTERNATIVE TO CONTROL GREEN MOLDS
}

\author{
Jasmina Glamočlija ${ }^{1}$, Marina Soković ${ }^{1}$, Vele Tešević ${ }^{2}$, Giani Andrea Linde ${ }^{3}$, Nelson Barros Colauto ${ }^{3^{*}}$ \\ ${ }^{1}$ Mycological Laboratory, Institute for Biological Research „Siniša Stanković“, University of Belgrade, Bulevar Despota Stefana \\ 142, 11000 Belgrade, Serbia; ${ }^{2}$ Faculty of Chemistry, University of Belgrade, Studentski trg 16, P.O. Box 158, 11000 Belgrade, \\ Serbia; ${ }^{3}$ Laboratório de Biologia Molecular, Universidade Paranaense, Umuarama, PR, Brasil.
}

Submitted: November 10, 2010; Returned to authors for corrections: January 21, 2011; Approved: May 16, 2011.

\begin{abstract}
The essential oil of Lippia alba is reported as an antifungal against human pathogenic microorganisms but few articles report its use as an alternative to synthetic fungicides on green mould control. The objective of this study was to determine chemical characteristics of $L$. alba essential oil and its antifungal activity against green molds as an alternative to synthetic fungicides. Essential oil was extracted by Clevenger hydrodistillation, characterized by GC-MS analysis, and the structure of the main compounds confirmed by ${ }^{1} \mathrm{H}$ and ${ }^{13} \mathrm{C}-\mathrm{NMR}$ spectroscopy. Microdilution assays evaluated the essential oil minimum inhibitory concentration (MIC) and minimum fungicidal concentration (MFC). Commercial fungicides Ketoconazole and Bifonazole were used as control. Essential oil yield is of $0.15 \%$ and the major components are neral (33.32\%) and geranial (50.94\%). The L. alba essential oil has MIC of $0.300-1.250 \mathrm{mg} / \mathrm{mL}$ and MFC of 0.600-1.250 mg/mL. Ketoconazole and Bifonazole show MIC ranging from 0.025-0.500 to 0.100-0.200 $\mathrm{mg} / \mathrm{mL}$, and MFC ranging from $0.250-0.100$ to $0.200-0.250 \mathrm{mg} / \mathrm{mL}$, respectively. L. alba essential oil is classified as citral type and the results indicate that it is a potential alternative to synthetic fungicides.
\end{abstract}

Key words: antifungal, essential oil, neral, geranial, Lippia alba.

\section{INTRODUCTION}

Lippia alba (Mill.) N.E. Br. ex Britton \& P. Wilson (Verbenaceae) is an aromatic plant widely used all over South and Central America for different purposes. This family comprises over 175 genera and 2,800 species in Africa, Latin America (25) and India $(6,32)$. Several papers have presented ethnopharmacological studies dealing with $L$. alba as sedative, antidepressant and analgesic properties (18). The essential oil of L. alba also has many applications such as stomachic, antispasmotic, digestive, anti-hemorrhoidal and anti-asthmatic (18). Different biological activities such as cytotoxic, antifungal, antibacterial, antiviral and anti-inflammatory, have been identified in essential oils or extracts of $\operatorname{L}$. alba $(5,11,19$, 26, 37).

Mesa-Arango et al. (25) reported two chemotypes, citral

\footnotetext{
*Corresponding Author. Mailing address: Molecular Biology Laboratory, Postgraduate Program on Agricultural Biotechnology, Paranaense University. Praça Mascarenhas de Moraes 4282 - CEP 87502-210, Umuarama-PR, Brazil.; E-mail: nbc@unipar.br
} 
and carvone but Tavares et al. (35) reported three chemotypes, citral, carvone and linalool for the same species. Shukla et al. (32), Tavares et al. (35) and Mesa-Arango et al. (25) stated that the main constituents of $L$. alba essential oil were geranial varying from $22.21 \%$ to $33.98 \%$ and neral varying from $14.20 \%$ to $25.82 \%$. Although L. alba essential oil is well described, its chemotypes and constituents may vary according to the environment. Thus, it is important to determine the chemical characterization of L. alba essential oil in order to identify the components that have antifungal activity.

The antifungal activity of the essential oils of $L$. alba against human pathogenic fungi such as Candida albicans, Candida guilliermondii, Candida parapsilosis, Candida neoformans, Trichophyton rubrum and Fonsecaea pedrosoi has been previously demonstrated for the citral and myrcene-citral chemotypes (26). L. alba essential oil and two of its major components were evaluated for fungitoxicity and antiaflatoxigenicity against Aspergillus flavus (32). The antifungal activity was evaluated against $C$. parapsilosis, Candida krusei, A. flavus and Aspergillus fumigatus strains (25). Antifungal screening was carried out also against Saccharomyces cerevisiae, A. flavus, Aspergillus niger and C. albicans (6).

Although many studies reported the antifungal activity of L. alba essential oils against human pathogenic microorganisms, few articles were about Fusarium, Aspergillus and Penicillium genera (34). These fungi are well known as causal agents of food-borne diseases and food spoilage, which increase the costs of food production and health care in the world (24). In addition, the genera Trichoderma, Aspergillus and Penicillium, known as green moulds, occur on mushroom production when the composting is not correctly prepared and/or does not become selective enough (15). Those fungi can spread very rapidly competing for carbohydrates in the substrate at the time of spawning, or in the casing layer, and some of them produce toxins that can damage mushroom tissue
(15). The genus Trichoderma is the most common contaminant on mushroom cultivations and facilities causing enormous economic losses around the world (9). Many sanitary procedures were adopted in mushroom farms to control Trichoderma sp and other green molds (15) and also on spawn production or spawning procedures where synthetic fungicides are used on mushroom cultivation. Although the fungicides that are commonly used in cultivation are very effective and inexpensive, it has been suggested that they leave residual toxicity that may cause side effects, including carcinogenesis and teratogenesis $(20,23,33)$. Most of these synthetic fungicides have been restricted in several countries since the early 1960's.

Despite of the potential use of essential oils on fungus control, there are no reports about the essential oil toxic effects on basidiomycete development or the use on mushroom production. Thus, new studies should be done to evaluate the viability of spraying essential oil solutions on the surface of casing layers where green molds are very common. Also, microbicidal essential oils are generally considered less harmful than synthetic chemicals and are being used on other organic cultures (28). An additional advantage of essential oils is their volatile nature, which implies on low or no residues after treatment and low environmental impact.

Based on alternatives for organic production with natural substances to control undesirable fungi, the objective of this study was to determine the chemical characteristics of $L$. alba essential oil and its antifungal activity against green molds as an alternative to synthetic fungicides.

\section{MATERIALS AND METHODS}

\section{General}

The major equipment used was gas chromatography-mass spectrometry (GC-MS) 7890 (Agilent-Technologies, California, USA), nuclear magnetic resonance (NMR) spectrometer Varian GEMINI 2000 and Clevenger-type hydro 
distillation apparatus. All other chemicals (analytical grade) Glamočlija, J. et al.

study were from Merck (Darmstadt, Germany), unless stated otherwise. Malt agar and Sabourad maltose agar were from the Institute of Immunology and Virology, Torlak (Belgrade, Serbia); Ketoconazole (Galenika, a.d. Belgrade, Serbia) and Bifonazole (Srbolek, Belgrade, Serbia).

\section{Plant Material}

Leaves of L. alba were collected in the morning at nine o'clock from March to May in 2009, in the Medicinal Plant Garden at Paranaense University-Campus of Umuarama Brazil. Dirt was removed with tap water and stored in polyethylene plastic bags at $-20{ }^{\circ} \mathrm{C}$.

\section{Extraction of the essential oil}

Defrosted leaves (100 g) were transferred to a Clevenger apparatus for hydrodistillation for one hour. The essential oil extracted was stored at $-20{ }^{\circ} \mathrm{C}$ and the yield was determined by the essential oil volume obtained in $100 \mathrm{~g}$ of leaves, expressed in percentage of volume per mass (mL/100 $\mathrm{g}$ of leaves x 100).

\section{Analysis of essential oil}

GC-MS analysis: the GC-MS analysis was performed using an Agilent 7890 gas chromatograph coupled to an Agilent $5975 \mathrm{C}$ mass selective detector (MSD) in the positive ion electron impact (EI) mode. The separation was achieved using an HP-5MS fused silica capillary column, $30 \mathrm{~m} \times 0.25$ $\mathrm{mm}$ i.d., $0.25 \mu \mathrm{m}$ film thickness. GC oven temperature was programmed from $60{ }^{\circ} \mathrm{C}$ to $285{ }^{\circ} \mathrm{C}$ at a rate of $4.3{ }^{\circ} \mathrm{C} / \mathrm{min}$. Helium was used as the carrier gas; inlet pressure was $25 \mathrm{kPa}$; linear velocity: $1 \mathrm{~mL} / \mathrm{min}$ at $210^{\circ} \mathrm{C}$. Injector temperature: 250 ${ }^{\circ} \mathrm{C}$ and injection mode: split 1:50. MS scan conditions: source temperature, $200{ }^{\circ} \mathrm{C}$; interface temperature, $250{ }^{\circ} \mathrm{C}$; E energy, $70 \mathrm{eV}$; mass scan range, 40-350 amu.

Identification of compounds: a library search and mass spectral deconvolution and extraction were performed using Automated Mass Spectral Deconvolution and Identification dimethylsulfoxide (DMSO), ethanol, and methanol used in this L. alba essential oil to control green molds

System (NIST AMDIS) software version 2.4, using retention index (RI) calibration data analysis parameters with 'strong' level and 7\% penalty for compounds without an RI. The RI was experimentally determined using the standard method (1, 36) involving retention times of $n$-alkanes, injected after the essential oil under the same chromatographic conditions. The search was performed against our own library containing 4951 spectra. The percentage (relative) of the identified compounds was computed from $\mathrm{GC}$ peak area.

NMR spectroscopy: ${ }^{1} \mathrm{H}$ and ${ }^{13} \mathrm{C}$ NMR spectra were recorded on Varian GEMINI 2000 spectrometer $(200 \mathrm{MHz}$ for ${ }^{1} \mathrm{H} ; 50 \mathrm{MHz},{ }^{13} \mathrm{C}$ ) in $5 \mathrm{~mm}$ standard tubes. Chemical shifts are given on the $\delta$ scale relative to TMS as internal standard.

\section{Antifungal activity}

For the bioassays, seven fungal strains were used: Aspergillus ochraceus (ATCC 12066), Aspergillus versicolor (ATCC 11730), A. niger (ATCC 6275), A. fumigatus (ATCC 9142), Penicillium ochrochloron (ATCC 9112), Penicillium funiculosum (ATCC 10509) and Trichoderma viride (IAM 5061). All of the tested organisms were from the Mycological Laboratory, Department of Plant Physiology, Institute of Biological Research „Siniša Stanković“, Belgrade, Serbia. The micromycetes were maintained on malt agar (MA) and Sabouraud agar (SBA), stored at $4{ }^{\circ} \mathrm{C}$ and subcultured once a month (7).

Microdilution method: in order to investigate antifungal activity of the isolated essential oil a modified microdilution technique was used $(12,17)$. The fungal spores were washed from the surface of agar plates with sterile $0.85 \%$ saline containing $0.1 \%$ Tween $80(\mathrm{v} / \mathrm{v})$. The fungal cell suspension was adjusted with sterile saline to a concentration of $1.0 \times 10^{6}$ in a final volume of $100 \mu \mathrm{L}$ per well. The inocula were stored at $4{ }^{\circ} \mathrm{C}$ for further use. Dilutions of the inocula were cultured 
on solid MA for fungi to verify the absence of contamination and the validity of the inoculum.

Glamočlija, J. et al.

microtitre plates. The investigated essential oil was added in broth malt medium with inoculum. The microplates were incubated for five days at $25{ }^{\circ} \mathrm{C}$ for fungi. The lowest concentrations without visible growth under optical microscope were defined as MIC.

The minimum fungicidal concentration (MFC) was determined by serial subcultivation of $2 \mu \mathrm{L}$ into microtitre plates containing $100 \mu \mathrm{L}$ of broth per well and further incubation for $72 \mathrm{~h}$ at $25^{\circ} \mathrm{C}$. The lowest concentration with no visible growth under optical microscope was defined as MFC indicating 99.5\% killing of the original inoculum. Each experiment was done in triplicate. Ketoconazole and Bifonazole were used as positive controls $(1 \mathrm{mg} / \mathrm{mL})$.

\section{RESULTS AND DISCUSSION}

L. alba essential oil yield, in this work, was of $0.15 \%$ but Shukla et al. (32) reported yield of 0.08\%, and Castro et al. (10) reported yield ranging from 0.15 to $0.61 \%$ where higher yields were from leaves collected in the summer. L. alba leaves represent $80 \%$ of the total plant mass with an annual production of five tons per hectare in Brazil. Although few agronomical studies were done on the genetic improvement of this plant or on the essential oil yield (2), it is still a potential plant for studies on diversification of farm production. Such issues are valid worldwide, but they are especially true in areas in which cultivation is constrained by environmental and economic factors that often reduce rural areas to marginal conditions. Thus, new culture opportunities have become an important topic in agricultural research.
Minimum inhibitory concentration (MIC) determination was performed by a serial dilution technique using 96-well L. alba essential oil to control green molds

The chemical analysis of $L$. alba essential oil showed that geranial $(50.94 \%)$ and neral $(33.32 \%)$ are the main components. $97.69 \%$ of the total essential oil was identified (Table 1) and could be classified as a citral chemotype based on their chemical constituents. Monoterpenes neral and geranial were the main constituents of the citral chemotype (25). For L. alba, two chemotypes, citral and carvone, are reported by Mesa-Arango et al. (25) and three chemotypes, citral, carvone and linalool, are reported by Tavares et al. (35). For the same plant species, essential oil composition and yield can vary according to harvesting seasons, part of the plant and geographical cultivation location (8). For instance in general, essential oils from leaves harvested during or immediately after flowering possess stronger antimicrobial activity (8). Also, different essential oil chemical composition has been found among seeds and immature leaves of coriander (Coriandrum sativum L.) (8). For L. alba, genetic factors seems to be the principal responsible for variations on chemical constituents more than environmental ones (35). Shukla et al. (32) reported that the main constituents of L. alba essential oil were geranial (22.21\%) and neral (14.20\%), Tavares et al. (35) reported that they were geranial (33.98\%) and neral (25.82\%) and Mesa-Arango et al. (25) reported that they were geranial (30.5\%) and neral (23.6\%). The quantity of geranial and neral was more concentrated in our study, 50.94\% and $33.32 \%$, respectively (Table 1), than in the ones reported in previously cited literature.

In order to confirm the structure of the main compounds, the essential oil was studied by ${ }^{1} \mathrm{H}$ and ${ }^{13} \mathrm{C}$-NMR spectroscopy. The essential oil ${ }^{1} \mathrm{H}$ NMR spectrum (Figure 1) gave resonances for a mixture of two isomers as indicated by the disparity in 
single hydrogen peaks. Signals due to aldehyde protons were detected as two doublets at $89.99(\mathrm{~J}=8.0 \mathrm{~Hz})$ and $9.90(\mathrm{~J}=8.0$ $\mathrm{Hz}$ ). From the NMR integration of those peaks, the ratio between the two components was determined to be 1:0.67. The presence of neral and geranial is supported by ${ }^{13} \mathrm{C}$ NMR data (Table 2), according to Ragasa et al. (30).

L. alba essential oil has antifungal activity with MIC in a Glamočlija, J. et al. range of $0.300-1.250 \mathrm{mg} / \mathrm{mL}$, and $\mathrm{MFC}$ in a range of $0.600-$ $1.250 \mathrm{mg} / \mathrm{mL}$ (Table 3). The commercial preparation of fungicidal agent, Ketoconazole, showed MIC in a range of $0.025-0.500 \mathrm{mg} / \mathrm{mL}$ and $\mathrm{MFC}$ in a range of $0.250-0.100$ $\mathrm{mg} / \mathrm{mL}$. Bifonazole showed lower antifungal activity with a MIC of $0.100-0.200 \mathrm{mg} / \mathrm{mL}$ and MFC of $0.200-0.250 \mathrm{mg} / \mathrm{mL}$ (Table 3).

L. alba essential oil to control green molds

Table 1. The chemical composition of essential oil of Lippia alba.

\begin{tabular}{|c|c|c|}
\hline Compound & RI & $\%$ \\
\hline 1-Oct-en-3-ol & 968 & 0.45 \\
\hline 2-methyl-1-Hepten-6-one & 979 & 0.37 \\
\hline Myrcene & 984 & 0.50 \\
\hline Linalol & 1090 & 0.49 \\
\hline$\beta$-Pinene oxide & 1142 & 0.18 \\
\hline (Z)-Isocitral & 1158 & 0.23 \\
\hline Rosefuran epoxide & 1170 & 0.19 \\
\hline Neral & 1244 & 33.32 \\
\hline Piperitone & 1252 & 0.22 \\
\hline Geranial & 1277 & 50.94 \\
\hline$p$-Menth-1 en-7-al & 1281 & 0.71 \\
\hline $\mathrm{Nd}$ & 1360 & 0.72 \\
\hline$\alpha$-Copaene & 1372 & 0.24 \\
\hline$\beta$-Elemene & 1389 & 0.27 \\
\hline (E)-Caryophyllene & 1417 & 3.07 \\
\hline$\alpha$-Humulene & 1450 & 0.21 \\
\hline Germacrene D & 1479 & 0.14 \\
\hline Aciphyllene & 1504 & 0.53 \\
\hline Cubebol & 1513 & 0.31 \\
\hline$\delta$-Cadinene & 1521 & 0.20 \\
\hline $\mathrm{Nd}$ & 1531 & 0.12 \\
\hline (E)-Nerolidol & 1561 & 0.52 \\
\hline Caryophyllene oxide & 1580 & 2.17 \\
\hline Allo-aromadendrene epoxide & 1648 & 2.43 \\
\hline $\mathrm{Nd}$ & 1660 & 0.43 \\
\hline $\mathrm{Nd}$ & 2107 & 0.24 \\
\hline $\mathrm{Nd}$ & 2237 & 0.15 \\
\hline $\mathrm{Nd}$ & 2326 & 0.13 \\
\hline Total & & 97.69 \\
\hline
\end{tabular}

Legend: RI: retention index; Nd: not determined.

Table 2. $200 \mathrm{MHz}{ }^{1} \mathrm{H}$ NMR and $50 \mathrm{MHz}{ }^{13} \mathrm{C}$ NMR spectral data of neral and geranial from Lippia alba essential oil. 


\begin{tabular}{ccccc}
\hline & $\boldsymbol{\delta}_{\mathbf{C}}$ & $\boldsymbol{\delta}_{\mathbf{H}}$ mult. (J Hz) & $\boldsymbol{\delta}_{\mathbf{C}}$ & $\boldsymbol{\delta}_{\mathbf{H}}$ mult. (J Hz) \\
\hline 1 & 191.50 & $9.99 \mathrm{~d}(8.0 \mathrm{~Hz})$ & 190.63 & $9.90(8.0 \mathrm{~Hz})$ \\
2 & 127.17 & $5.88 \mathrm{~d}(8.0 \mathrm{~Hz})$ & 128.73 & $5.88 \mathrm{~d}(8.0 \mathrm{~Hz})$ \\
3 & 163.98 & - & 163.98 & - \\
4 & 40.38 & 2.20 & 32.34 & 2.59 \\
5 & 25.53 & 2.17 & 27.82 & 2.17 \\
6 & 122.44 & 5.16 & 122.15 & 5.10 \\
7 & 132.96 & - & 133.44 & - \\
8 & 25.34 & 1.68 & 25.34 & 1.68 \\
9 & 17.40 & 1.61 & 17.40 & 1.61 \\
10 & 17.27 & 1.99 & 24.77 & 1.99 \\
\hline
\end{tabular}

Glamočlija, J. et al.

L. alba essential oil to control green molds

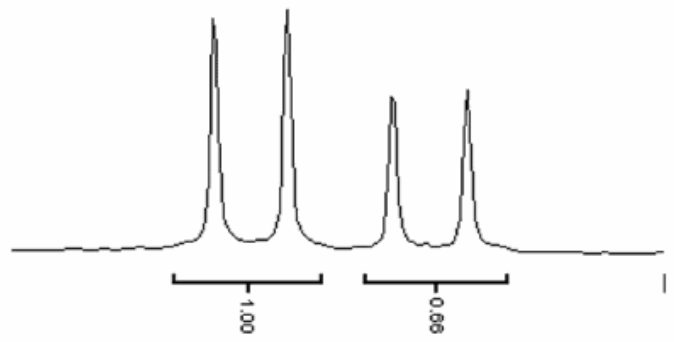

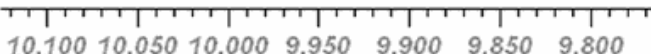

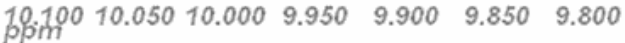

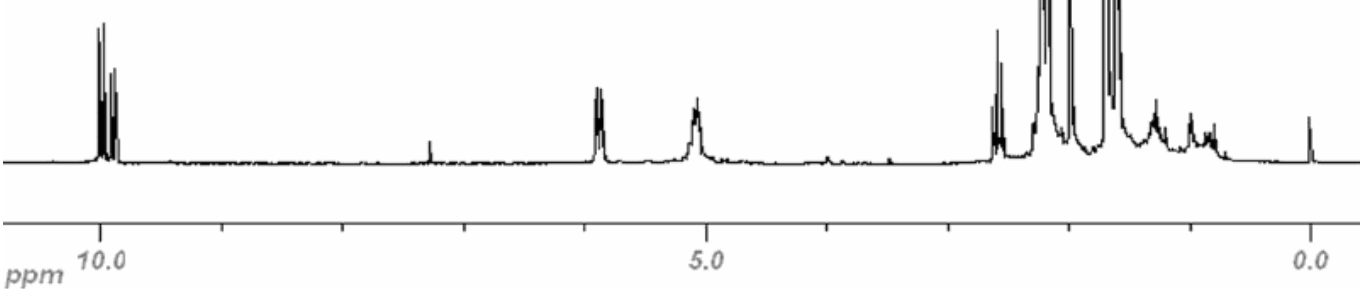

Lippia alba essential oil ${ }^{1} \mathrm{H}$ NMR spectra

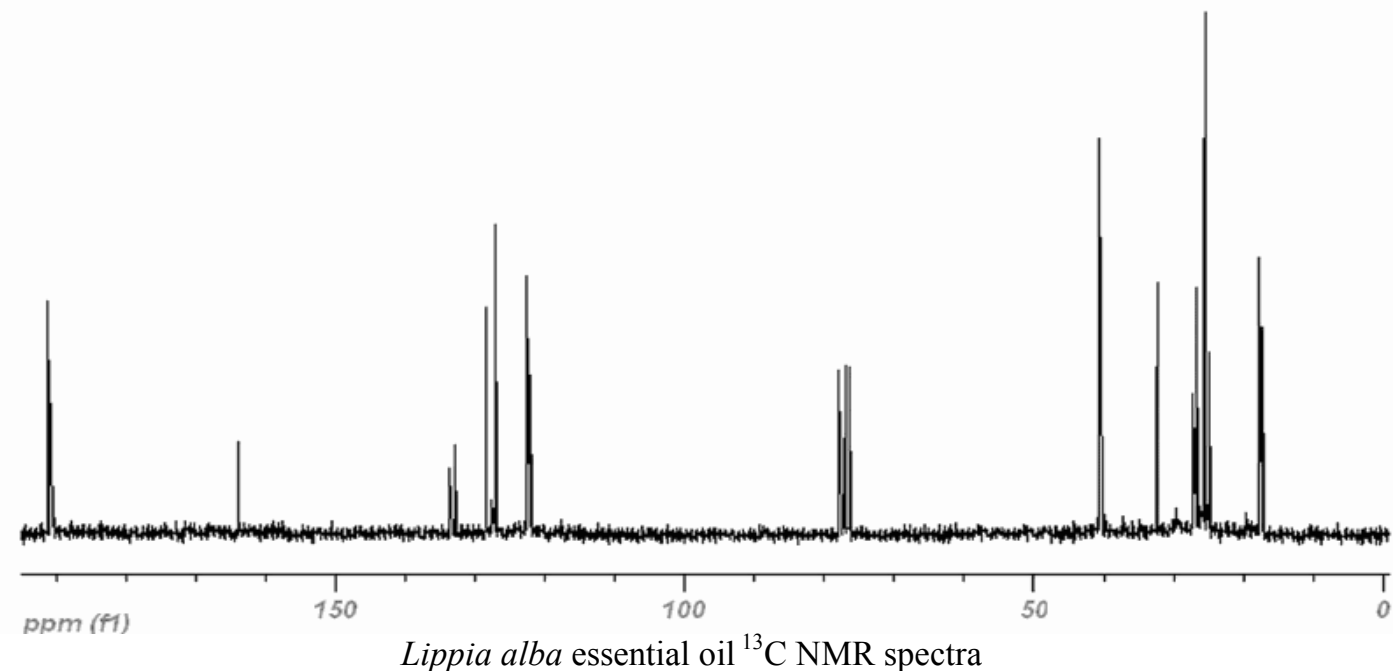




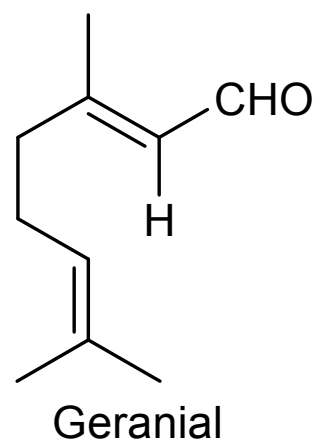

Figure 1. Lippia alba essential oil ${ }^{1} \mathrm{H}$ NMR and ${ }^{13} \mathrm{C}$ NMR spectra. Glamočlija, J. et al.<smiles>CC(C)=CCCC(C)=CC=O</smiles>

L. alba essential oil to control green molds

Table 3. Minimal inhibitory concentration (MIC) and minimal fungicidal concentration (MFC) of Lippia alba essential oil.

\begin{tabular}{|c|c|c|c|c|}
\hline Fungi & & Essential oil (mg/mL) & Ketoconazole $(\mathrm{mg} / \mathrm{mL})$ & Bifonazole (mg/mL) \\
\hline \multirow{2}{*}{ Aspergillus ochraceus } & $\mathrm{MIC}$ & $0.300 \pm 0.057$ & $0.025 \pm 0.150$ & $0.100 \pm 0.030$ \\
\hline & $\mathrm{MFC}$ & $0.600 \pm 0.057$ & $0.100 \pm 0.030$ & $0.200 \pm 0.050$ \\
\hline \multirow{2}{*}{ Aspergillus versicolor } & $\mathrm{MIC}$ & $0.300 \pm 0.057$ & $0.100 \pm 0.060$ & $0.100 \pm 0.030$ \\
\hline & MFC & $0.600 \pm 0.100$ & $0.025 \pm 0.020$ & $0.200 \pm 0.050$ \\
\hline \multirow{2}{*}{$\begin{array}{c}\text { Aspergillus } \\
\text { niger }\end{array}$} & $\mathrm{MIC}$ & $0.600 \pm 0.060$ & $0.025 \pm 0.057$ & $0.150 \pm 0.010$ \\
\hline & $\mathrm{MFC}$ & $0.600 \pm 0.057$ & $0.025 \pm 0.010$ & $0.200 \pm 0.057$ \\
\hline \multirow{2}{*}{ Aspergillus fumigatus } & $\mathrm{MIC}$ & $0.300 \pm 0.100$ & $0.025 \pm 0.057$ & $0.150 \pm 0.030$ \\
\hline & MFC & $1.250 \pm 0.230$ & $0.050 \pm 0.010$ & $0.200 \pm 0.100$ \\
\hline \multirow{2}{*}{ Penicillium ochrochloron } & MIC & $0.600 \pm 0.057$ & $0.010 \pm 0.080$ & $0.150 \pm 0.020$ \\
\hline & MFC & $1.250 \pm 0.057$ & $0.025 \pm 0.010$ & $0.200 \pm 0.100$ \\
\hline \multirow{2}{*}{ Penicillium funiculosum } & MIC & $1.250 \pm 0.000$ & $0.025 \pm 0.010$ & $0.200 \pm 0.030$ \\
\hline & MFC & $1.250 \pm 0.057$ & $0.050 \pm 0.057$ & $0.250 \pm 0.030$ \\
\hline \multirow{2}{*}{$\begin{array}{c}\text { Trichoderma } \\
\text { viride }\end{array}$} & MIC & $0.600 \pm 0.057$ & $0.050 \pm 0.010$ & $0.200 \pm 0.050$ \\
\hline & MFC & $1.250 \pm 0.230$ & $0.100 \pm 0.030$ & $0.250 \pm 0.057$ \\
\hline
\end{tabular}

The results are expressed as mean \pm standard deviation.

L. alba essential oil for antifungal screening was performed in vitro by disc diffusion method against $S$. cerevisiae, A. flavus, A. niger and C. albicans and showed mild to moderate activity (6). Essential oil of $L$. alba and two of its components (geranial and neral) are highly effective against production of aflatoxin B1 by A. flavus (32), presenting high activity against gram-positive bacteria with MIC of $0.300-$ $0.630 \mathrm{mg} / \mathrm{mL}$, mainly Staphylococcus aureus and Pseudomonas aeruginosa (4). In our study, it is clear that geranial and neral are the main components of $L$. alba essential oil being geranial the prime component. Shukla et al. (32) reported that geranial from L. alba caused 100\% inhibition growth on 13 fungi among 17 tested; whereas, at the same concentration, the essential oil and neral component presented $100 \%$ of inhibition just on 9 and 2 fungal species, respectively. Thus, geranial seems to be the main fungicidal component of $L$. alba essential oil. The high geranial concentration of $L$. alba essential oil in our work may explain the good antifungal results and it is an alternative to synthetic fungicides such as Ketoconazole and Bifonazole on health, food and agriculture.

The development of applications for L. alba essential oil is still not well-explored. Rao et al. (31) reported antifungal activity against sugarcane pathogens and Lee et al. (21) and Park et al. (27) reported bioactivity of geranial and neral 
against phytopathogens and dermatophytes, but no reports were found about $L$. alba essential oil against $T$. viride. The results of the present study on the effectiveness of L. alba essential oil against micromycetal food poisoning, fungus, plant, animal and human pathogens showed excellent antifungal activity. The essential oil MIC described in the literature for $T$. viride was $1.4 \mu \mathrm{g} / \mathrm{mL}$ for Nepeta rtanjensis (16), $25 \mu \mathrm{L} / \mathrm{mL}$ for Salvia sclarea (13) and $0.42 \mu \mathrm{L} / \mathrm{mL}$ for Lippia gracilis (3). The results of our study show that L. alba essential oil is a Glamočlija, J. et al.

however, it is suggested that Prochloraz and Benomyl may cause side effects (33). In addition, in many countries there is no effective control of those substances, making it difficult to detect misuse of those substances. L. alba essential oil may be used as a potential alternative to synthetic fungicides mainly on organic cultivation such as mushroom cultivation or encapsulated with cyclodextrins in food biofilms according to Linde et al. (22). However, further studies are required to develop strategies for application on health, food and agriculture.

\section{CONCLUSIONS}

It was concluded that L. alba essential oil is classified as citral type according to the presence of main components, neral (33.32\%) and geranial (50.94\%). The essential oil of $L$. alba presents antifungal activity with MIC of $0.300-1.250 \mathrm{mg} / \mathrm{mL}$ and MFC of $0.600-1.250 \mathrm{mg} / \mathrm{mL}$. The commercial fungicides Ketoconazole and Bifonazole show MIC in a range of 0.0250.500 and $0.100-0.200 \mathrm{mg} / \mathrm{mL}$ and $\mathrm{MFC}$ in a range of 0.250 0.100 and $0.200-0.250 \mathrm{mg} / \mathrm{mL}$, respectively. Geranial seems to be the main fungicidal component of $L$. alba essential oil. $L$. alba essential oil is a potential alternative to synthetic fungicides. However, further studies are required to develop strategies for application on health, food and agriculture.

\section{ACKNOWLEDGEMENTS}

fungicidal and fungistatic alternative to control T. viride. Geels et al. (15) reported that green moulds (Trichoderama, Aspergillus and Penicillium species) can occur on compost and/or casing layer causing mushroom production losses. In order to avoid green moulds, Benomyl (Benlate ${ }^{\circledR}$ ), among other fungicides that have a broad spectrum systemic fungicide, is used against a large number of important fungal pathogens on Agaricus bisporus cultivation $(14,29)$. Prochloraz (Sporgon ${ }^{\circledR}$ ) is another commonly used fungicide in mushroom cultivation; L. alba essential oil to control green molds

The authors are grateful to the Ministry of Science and Technological Development of the Republic of Serbia for the financial support, Pr. n. 173032 and 172053, and to the Paranaense University.

\section{REFERENCES}

1. Adams, R.P. (2007). Identification of Essential Oil Components by Gas Chromatography/Mass Spectrometry, $4^{\text {th }}$ Ed. Allured Publishing Corporation. Carol Stream, Illinois, p. 50-490.

2. Aguiar, J.S.; Costa, M.C.C.D. (2005). Lippia alba (Mill.) N. E. Brown (Verbenaceae): levantamento de publicações nas áreas química, agronômica e farmacológica, no período de 1979 a 2004. Rev. Plantas Med. Bot. 8 (1), 79-84.

3. Albuquerque, C.C.; Camara, T.R.; Mariano, R.L.R.; Willadino, L.; Marcelino C.; Ulisses, C. (2006). Antimicrobial action of the essential oil of Lippia gracilis Schauer. Braz. Arch. Biol. Technol. 49, (4), 527-535.

4. Alea, J.A.; Luis, A.G.; Peréz, A.R.; Jorge, M.R.; Baluja, R. (1997). Composición y propiedades antibacterianas del aceite esencial de Lippia alba (Mill.) N. E. Br. Rev. Cubana Farm. 30, 29-35.

5. Andrighetti-Frohner, C.R.; Sincero, T.C.M.; da Silva, A.C.; Savi, L.A.; Gaido, C.M.; Bettega, J.M.R.; Mancini, M.; de Almeida, M.T.R.; Barbosa, R.A.; Farias, M.R.; Barardi, C.R.M.; Simoes, C.M.O. (2005). Antiviral evaluation of plants from Brazilian atlantic tropical forest. Fitoterapia 76, 374-378.

6. Ara, N.; Nur. M.N.; Arman, M.S.; Wahid, M.I.I.; Ahmed, M. (2009). In vitro antimicrobial and cytotoxic activities of leaves and flowers extracts from Lippia alba. Pak. J. Biol. Sci. 12, 87-90.

7. Booth, C. (1971). Fungal Culture Media. In: Norris, J.R., Ribbons, D.W. (eds.) Methods in Microbiology. London \& New York: Academic Press, p. 49-94.

8. Burt, S. (2004). Essential oils: their antibacterial properties and potential applications in foods-a review. Int. J. Food. Microbiol. 94, 223-253.

9. Castle, A.; Speranzini, D.; Rghei, N.; Alm, G.; Rinker, D.; Bissett, J. 
(1998). Morphological and molecular identification of Trichoderma isolates on north american mushroom farms. Appl. Environ. Microbiol. 64, 133-137.

10. Castro, D.M.; Ming, L.C.; Marques, M.O.M. (2002). Biomass production and chemical composition of Lippia alba (Mill.) N. E. Brown Britt \& Wilson in leaves on different plant parts in different seasons. Acta Hort. (ISHS) 569, 111-115.

11. Costa, M.C.C.D.; Aguilar, J.S.; do Nascimento, S.C. (2004). Atividade citotóxica de extratos brutos de Lippia alba (Mill.) N.E. Brown (Verbenaceae). Acta Farm. Bonaeren. 23, 349-352.

12. Daouk, K.D.; Dagher, M.S.; Sattout, J.E. (1995). Antifungal activity of the essential oil of Oryganum syriacum L. J. Food. Prot. 58, 1147-1149.

13. Džamić, A.; Soković, M.; Ristić, M.; Grujić-Jovanović, S.; Vukojević, J.; Glamočlija, J. et al.

16. Grbić M.L.; Stupar, M.; Vukojević, J.; Soković, M.; Mišić, D.; Grubišić, D.; Ristić, M. (2008). Antifungal activity of Nepeta rtanjensis essential oil. J. Serb. Chem. Soc. 73, 961-965.

17. Hanel, H.; Raether W. (1988). A more sophisitcated method for determinig the fungicidal effect of water-insoluble preparations with a cell harvester, using miconazole as an example. Mycoses 31, 148-154.

18. Hennebelle, T.; Sahpaz, S.; Joseph, H.; Bailleul, F. (2008). Ethnopharmacology of Lippia alba. J. Ethnopharm. 116, 211-222.

19. Holetz, F.B.; Pessini, G.L.; Sanches, N.R.; Cortez, D.A.G.; Nakamura, C.V.; Filho, B.P.D. (2002). Screening of some plants used in the Brazilian folk medicine for the treatment of infectious diseases. Mem. Inst. Oswaldo Cruz 97, 1027-1031.

20. Kato, T.; Ogiso, T.; Kato, K.; Sano, M.; Hasegawa, R.; Shirai, T.; Ito, N. (1995). Lack of promoting activity of four pesticides on induction of preneoplastic liver cell foci in rats. Terat. Carcin. Mutag. 15, 251-257.

21. Lee, Y.S.; Kim, J.; Shin, S.C.; Lee, S.G.; Park, I.K. (2008). Antifungal activity of Myrtaceae essential oils and their components against three phytopathogenic fungi. Flavour and Fragrance Journal 23, 23-28.

22. Linde, G.A.; Laverde Jr, A.; Colauto, N.B. (2011). Changes to taste perception in the food industry: use of cyclodextrins. In: Preedy, V.R.; Martin, C.R.; Watson, R.R. (eds.) Handbook of Behavior, Food and Nutrition. Springer, New York, USA, p. 99-118. DOI: 10.1007/978-0387-92271-3_8.

23. McCarroll, N.E.; Protzel, A.; Ioannoui, Y.; Frank Stack, H.F.; Jackson, M.A.; Waters, M.D.; Dearfield, K.L. (2002). A survey of EPA Opp and open literature on selected pesticide chemicals. III Mutagenicity and carcinogenicity of benomyl and carbendazim. Mutat. Res. 512, 1-35.

24. Mead, P.S.; Slutsker, L.; Dietz, V.; McCaig, L.F.; Breese, J.S.; Shapiro, C.; Griffin, P.M.; Tauxe, R.V. (1999). Food related illness and dead in the United States. Emer. Infec. Dis. 5, 607-625.

25. Mesa-Arango, A.C.; Montiel-Ramos, J.; Zapata, B.; Durán, C.; BetancurGalvis, L.; Stashenko, E. (2009). Citral and carvone chemotypes from the essential oils of Colombian Lippia alba (Mill.) N.E. Brown:
Marin, P.D. (2008). Chemical composition and antifungal activity of Salvia sclarea (Lamiaceae) essential oil. Arch. Biol. Sci., Belgrade 60, 233-237.

14. Eziashi, E.I.; Omamor, I.B.; Odigie, E.E. (2007). Antagonism of Trichoderma viride and effects of extracted water soluble compounds from Trichoderma species and benlate solution on Ceratocystis paradoxa. African Journal of Biotechnology 6, 388-392.

15. Geels, F.P.; Van de Geijn, J.; Rutjens, A.J. Pests and Diseases. In: Van Griensven, L.J.L.D. (ed.) The Cultivation of Mushrooms. Horst: Mushroom Experimental Station, 1988. p. 397-398.

\section{L. alba essential oil to control green molds}

composition, cytotoxicity and antifungal activity. Mem. Inst. Oswaldo Cruz 104, 878-884.

26. Oliveira, D.R.; Leitao, G.G.; Santos, S.S.; Bizzo, D.H.R.; Lopes, D.; Alviano, C.S.; Alviano, D.S.; Leitão, S.G. (2006). Ethnopharmacological study of two Lippia species from Oriximina, Brazil. J. Ethnopharmacol. 108, 103-108.

27. Park, M.J.; Gwak, K.S.; Yang, I.; Choi, W.S.; Jo, H.J.; Chang, J.W.; Jeung, E.B.; Choi, I.G. (2007). Antifungal activities of the essential oils in Syzygium aromaticum (L.) Merr. et Perry and Leptospermum petersonii Bailey and their constituents against various dermatophytes. Journal of Microbiology 45, 460-465.

28. Plooy, W.; Regnier, T.; Combrinck, S. (2009). Essential oil amended coatings as alternatives to synthetic fungicides in citrus postharvest management. Postharvest Biology and Technology 53, 117-122.

29. Potočnik, I.; Rekanović, E.; Milijašević, S.; Todorović, B. Stepanović, M. (2009). In vitro toxicity of fungicides of different mode of action to Agaricus bisporus (Lange) Imbach. Pestic. Phytomed. 24, 29-33.

30. Ragasa, C.Y; Ha, H.K.P.; Hasika, M.; Maridable, J.B.; Gaspillo, P.D.; Rideout, J.A. (2009). Antimicrobial and cytotoxic terpenoids from Cymbopogon citratus Stapf. Philipp. Scient. 45, 111-122.

31. Rao, G.P.; Singh, M.; Singh, P.; Singh, S.P.; Catalan, C.; Kapoor, I.P.S.; Singh, O.P.; Singh, G. (2000). Studies on chemical constituents and antifungal activity of leaf essential oil of Lippia alba (Mill). Indian Journal of Chemical Technology 7, 332-335.

32. Shukla, R.; Kumar, A.; Singh, P.; Dubey, N.K. (2009). Efficacy of Lippia alba (Mill.) N.E. Brown essential oil and its monoterpene aldehyde constituents against fungi isolated from some edible legume seeds and aflatoxin B1 production. Inter. J. Food Microbiol. 135, 165170 .

33. Soković, M.; Van Griensven L.J.L.D (2006). Antimicrobial activity of essential oils and their components against the three major pathogens of the cultivated button mushroom, Agaricus bisporus. Eur. J. Plant Path. $116,211-224$. 
34. Souza, E.L.; Lima, E.O.; Freire, K.R.L.; Sousa, C.P. (2005). Inhibitory action of some essential oils and phytochemicals on the growth of various moulds isolated from foods. Braz. Arch. Biol. Technol. 48, $245-$ 250.

35. Tavares, E.S.; Julião, L.S.; Lopes, D.; Bizzo, H.R.; Lage, C.L.S.; Leitão, S.G. (2005). Análise do óleo essencial de folhas de três quimiotipos de Lippia alba (Mill.) N. E. Br. (Verbenaceae) cultivados em condições semelhantes. Brazilian Journal of Pharmacognosy 15, 1-5.

36. Vandendool, H.; Kratz, P.D. (1963). A generalization of the retention index system including linear temperature programmed gas-liquid partition chromatography. J. Chromat. 11, 463-471.

37. Viana, G.S.B.; do Vale, T.G.; Rao, V.S.N.; Matos, F.J.A. (1998). Analgesic and antiinflammatory effects of two chemotypes of Lippia alba: a comparative study. Pharm. Biol. 36, 347-351. 